\title{
TRAINER SISTEM KENDALI ELEKTRONIK UNTUK PEMBELAJARAN MENGOPERASIKAN SISTEM KENDALI ELEKTRONIK
}

\author{
Fivia Eliza $^{1}$, Dwiprima Elvanny Myori ${ }^{2}$, Frinke Gentia Wireksi ${ }^{3}$ \\ 1,2,3 Jurusan Teknik Elektro, Fakultas Teknik, Universitas Negeri Padang \\ e-mail: fivia_eliza@yahoo.com
}

\begin{abstract}
The problem in learning Electronic Control System that implemented at SMKN 2 Lubuk Basung must be planned and made trainer as a learning media that can be used by tachers an the students, both individually change and together in the classroom. With the advent of the media, students can be learn optimally. This media is designed with the purpose of providing facilities in the learning processes, and keep track of Science and Technology, especially in the field of education in SMKN 2 Lubuk Basung. Media planning is structured in such a way based on the syllabus and the materials on subject of Electronic Control System. Media can replace the role of the teachers in presenting the material in front of the class, teachers and control only facilitates of the learning process. Students will follow a process of active learning, and regular interaction with the teacher, with the media or students.
\end{abstract}

Key words : Learning Modia, Trainer, MSKE

\begin{abstract}
ABSTRAK
Dalam pembelajaran Mengoperasikan Sistem Kendali Elektronik (MSKE) yang dilaksanakan di SMK N 2 Lubuk Basung perlu dirancang dan dibuat media pembelajaran trainer yang dapat dimanfaatkan oleh guru dan siswa, baik secara individu maupun secara bersama-sama di dalam kelas. Dengan adanya media ini, siswa tidak hanya mendapatkan penjelasan, melainkan juga bisa belajar mandiri secara bergantian. Trainer ini dirancang dengan tujuan memberikan kemudahan dalam proses pembelajaran, dan mengikuti perkembangan Ilmu Pengetahuan dan Teknologi terutama di bidang pendidikan di SMK Negeri 2 Lubuk Basung. Perancangan trainer ini disusun sedemikian rupa berdasarkan silabus dan materi pada mata pelajaran MSKE. Trainer ini dapat membantu guru dalam menyampaikan materi di depan kelas, guru memfasilitasi dan mengatur jalannya proses pembelajaran. Siswa akan mengikuti proses pembelajaran secara aktif, dan tetap berinteraksi baik dengan guru, dengan media maupun dengan sesama siswa.
\end{abstract}

Kata Kunci : Trainer, Electronis control system

\section{PENDAHULUAN}

Mata pelajaran Mengoperasikan Sistem Kendali Elektronik (MSKE) merupakan salah satu mata pelajaran produktif yang diberikan kepada siswa kelas XI program studi Teknik Instalasi Tenaga Listrik (TITL) di SMKN 2 Lubuk Basung. Pada mata pelajaran MSKE siswa mempelajari dan harus menyiapkan dirinya untuk mampu mengenal serta menguasai konsep sistem kendali elektronik yaitu komponen aktif (SCR, Transistor, TRIAC, dan IC). Media pembelajaran merupakan sarana yang dapat mendukung tercapainya tujuan pembelajaran. Ketersediaan media dalam proses pembelajaran mampu mempengaruhi kualitas hasil belajar peserta didik.

Penggunaan media dalam pembelajaran dapat meningkatkan motivasi dan minat belajar siswa. Hamalik dalam Azhar Arsyad mengemukakan bahwa hubungan komunikasi akan berjalan lancar dengan hasil maksimal apabila menggunakan alat bantu yang disebut media komunikasi. Penggunaan media yang 
tepat dalam pembelajaran Mengoperasikan Sistem Kendali Elektronik mampu menjadikan pemahaman yang abstrak menjadi lebih konkrit atau nyata. Media trainer sistem kendali elektronik digunakan sebagai perantara dalam proses pembelajaran mengoperasikan sistem kendali elektronik. Namun media trainer yang digunakan selama ini masih sederhana dan menyerupai papan rangkaian sehingga membutuhkan waktu lama dalam pengoperasiannya. Keterbatasan media yang digunakan selama ini menyebabkan media belum mampu mengoptimalkan hasil belajar mengoperasikan sistem kendali elektronik.

Media trainer sistem kendali elektronik dikembangkan agar mampu memberi solusi terhadap keterbatasan media trainer sistem kendali elektronik yang digunakan dalam proses pembelajaran. Tujuannya adalah agar siswa mudah memahami pelajaran dengan menggunakan trainer serta dapat menumbuhkan kemampuan intelektual, psikomotor, dan kualitas pembelajaran siswa. Berdasarkan keterbatasan media trainer yang ada tersebut menjadi latar belakang media trainer sistem kendali elektronik dikembangkan.

Media pembelajaran trainer sistem kendali elektronik yang dikembangkan diterapkan untuk mempelajari materi pada Kompetensi Dasar (KD) salah satunya adalah membuat rangkaian kendali elektronik sederhana. Mata pelajaran ini memiliki materi yang harus dipenuhi agar tercapainya tujuan dari kompetensi dasar yaitu: (1) SCR sebagai kontrol, (2) Transistor sebagai kontrol, (3) TRIAC sebagai kontrol, (4) IC sebagai kontrol. Materi ini tentunya harus terpenuhi agar siswa mengerti fungsi dan cara kerja rangkaian kendali elektronik sederhana.

Media trainer sistem kendali elektronik dirancang menarik agar siswa lebih termotivasi dalam mengikuti proses pembelajaran. Untuk menyampaikan pesan dari guru kepada siswa, biasanya guru menggunakan alat bantu mengajar (reaching aids) berupa gambar, model, atau alat bantu lain yang dapat memberikan pengalaman konkrit, motivasi belajar, serta mempertinggi daya serap atau yang kita kenal dengan alat bantu visual. Media yang dikembangkan didukung dengan jobsheet pembelajaran sebagai sumber belajar yang memungkinkan siswa belajar mandiri pada pelaksanaan pembelajaran.

Proses pembelajaran yang belum optimal menyebabkan siswa belum mampu berfikir kritis dan kreatif sehingga siswa sulit memahami materi pelajaran. Kelemahan tersebut berpengaruh pada hasil belajar siswa yang berada dibawah Kriteria Ketuntasan Minimum (KKM) yang diterapkan sekolah yaitu 75. Tentunya permasalahan ini tidak sesuai dengan Kurikulum Tingkat Satuan Pendidikan (KTSP) yang diterapkan yaitu $85 \%$ tuntas.

Berdasarkan permasalahan tersebut, upaya yang dapat dilakukan untuk meningkatkan keaktifan dan hasil belajar siswa pada mata pelajaran mengoperasikan sistem kendali elektronik adalah pengembangan media pembelajaran trainer sistem kendali elektronik yang valid, praktis, dan efektif. Pembelajaran mengoperasikan sistem kendali elektronik membutuhkan media yang bersifat kongkrit dan variatif dalam meningkatkan mutu pembelajaran. Media trainer sistem kendali elektronik yang dikembangkan mengajarkan siswa dalam memahami fungsi, prinsip kerja, dan merangkai kelistrikan sehingga mampu memberikan pengalaman langsung kepada siswa.

Menurut Slameto (2010), belajar merupakan suatu perubahan baru pada peserta didik karena adanya usaha yang dilakukan. Belajar adalah suatu proses usaha yang dilakukan seseorang untuk memperoleh suatu perubahan tingkah laku yang baru secara keseluruhan sebagai hasil pengalamannya dalam interaksi dengan lingkungannya. Sedangkan Sagala (2012), menyatakan belajar dikatakan berhasil apabila seseorang mampu mengulangi kembali materi yang telah dipelajarinya. 
Menurut Sudjana (2010), hasil belajar siswa pada hakikatnya adalah perubahan tingkah laku dan sebagai umpan balik dalam upaya memperbaiki proses belajar mengajar. Hasil belajar (achievement) merupakan realisasi atau pemekaran dari kecakapan-kecakapan potensial atau kapasitas yang dimiliki seseorang (Sukmadinata, 2011). Hasil belajar adalah kemampuan-kemampuan yang dimiliki siswa setelah ia menerima pengalaman belajar.

Berdasarkan pengertian hasil belajar diatas, dapat disimpulkan bahwa hasil belajar adalah kemampuan yang dimiliki siswa setelah mengikuti proses pembelajaran. Hasil belajar dapat dilihat dari kemampuan siswa yang meliputi ranah kognitif, afektif, dan psikomotor. Bloom mengemukakan secara garis besar hasil belajar menjadi tiga ranah, yaitu:

a. Ranah kognitif (Cognitive domain), adalah kawasan yang berkaitan dengan hasil belajar intelektual yang meliputi aspek pengetahuan, pemahaman, aplikasi, analisis, sintetis, dan evaluasi.

b. Ranah afektif (sikap), adalah kemampuan menerima atau menolak objek berdasarkan penilaian terhadap objek tersebut. Ranah afektif berkenaan dengan sikap dan nilai yang terdiri dari aspek reciving/ attending (penerimaan), responding (jawaban), valuing (penilaian), organisasi, dan karakteristik nilai atau internalisasi nilai.

c. Ranah psikomotor, berkenaan dengan bentuk keterampilan (skill) dan kemampuan bertindak individu. Terdiri dari gerakan refleks, keterampilan pada gerakan-gerakan dasar, kemampuan perseptual, kemampuan dibidang fisik, gerakan-gerakan skill, dan kemampuan yang berkenaan dengan komunikasi nondecursive seperti gerakan ekspresif dan interpretatif.

Usaha dan keberhasilan belajar dipengaruhi oleh banyak faktor. Faktor-faktor tersebut dapat bersumber dari dalam diri peserta didik atau dari luar dirinya. Penggunaan media pembelajaran juga mempengaruhi hasil belajar siswa. Pemilihan media yang tepat dapat memenuhi kebutuhan atau mencapai tujuan belajar yang diinginkan.

Media berasal dari bahasa Latin medius yang secara harfiah berarti "tengah, perantara, atau pengantar". Gagne menyatakan bahwa "media adalah berbagai jenis komponen dalam lingkungan siswa yang dapat merangsangnya untuk belajar" (Sadiman, 2009). Media memiliki peranan penting yaitu piranti (wahana) penyalur pesan atau informasi.

Media yang digunakan dalam dunia pendidikan disebut media pembelajaran. Gagne dan Briggs menyatakan bahwa media pembelajaran meliputi alat yang secara fisik digunakan untuk menyampaikan isi materi pengajaran yang terdiri dari buku, tape recorder, kaset, video camera, video recorder, film, slide (gambar bingkai), foto, gambar, grafik, televisi, dan komputer. Berdasarkan uraian diatas, penggunaan media pembelajaran harus didasarkan pada pemilihan yang tepat, sehingga dapat memperbesar arti dan fungsi dalam menunjang efektivitas dan efisiensi proses pembelajaran (Arsyad, 2013).

Dengan memperhatikan kompleks dan uniknya proses belajar, maka ketepatan pemilihan media dan metode pembelajaran akan sangat berpengaruh terhadap hasil belajar siswa. J Bruner mengemukakan bahwa dalam proses pembalajaran hendaknya menggunakan urutan dari belajar dengan gambaran atau film (iconic representation of experiment) kemudian ke belajar dengan simbol, yaitu mengunakan kata-kata (symbolic representation) (Hamalik, 2000). Edgar Dale mengelompokkan media pembelajaran berdasarkan jenjang pengalaman yang diperoleh pembelajar. Jenjang pengalaman itu disusun dalam suatu bagan yang dikenal dengan nama Dale's Cone of Experience (kerucut pengalaman Dale) sebagai berikut: 


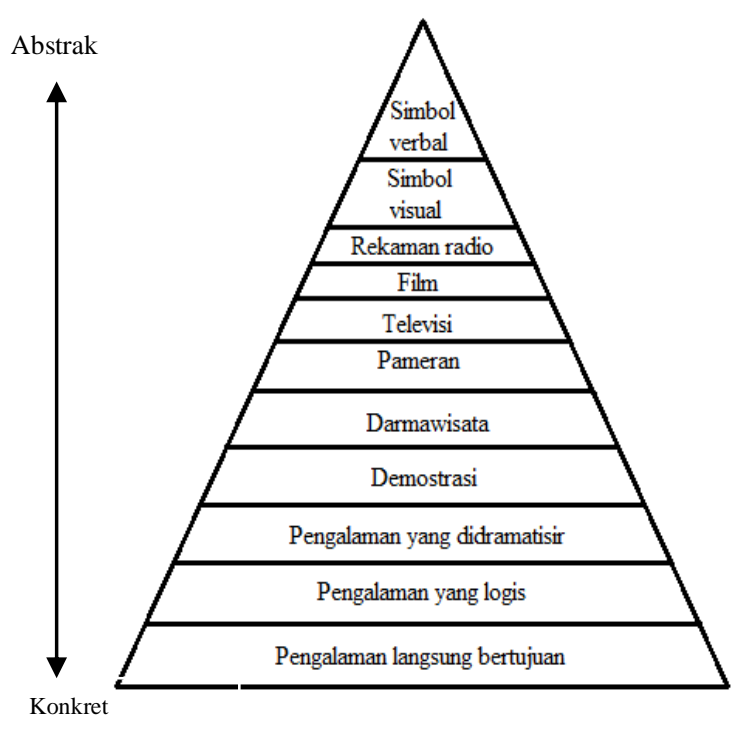

Gambar 1. Kerucut Pengalaman belajar

Gambar 1 menjelaskan bahwa semakin keatas klasifikasi media maka pengalaman belajar siswa semakin abstrak. Sebaliknya bila semakin kebawah klasifikasi media maka pengalaman belajar yang didapat siswa semakin konkrit. Artinya penggunaan media real objek lebih efektif meningkatkan pengalaman belajar siswa.

Penggunaan media pembelajaran dapat meningkatkan efisiensi proses dan mutu hasil belajar mengajar. Dengan menggunakan media pembelajaran tujuan proses belajar mengajar dapat dicapai dengan baik (Daryanto, 2010).

Guru dapat menggunakan dan mengembangkan media pembelajaran dalam proses belajar mengajar. Media yang dapat dimanfaatkan oleh guru adalah media yang sesuai dengan tujuan pembelajaran. Pada mata pelajaran mengoperasikan sistem kendali elektronik, penggunaan dan pengembangan media pembelajaran trainer menjadi pilihan yang tepat untuk meningkatkan hasil belajar siswa.

Trainer merupakan proses simulasi aplikasi membangun model dari sistem nyata atau usulan sistem, melakukan eksperimen dengan model tersebut untuk menjelaskan perilaku sistem, atau untuk membangun sistem baru sesuai dengan kinerja yang dinginkan. Trainer merupakan suatu set peralatan di laboratorium yang digunakan sebagai media pendidikan yang merupakan gabungan antara model kerja dan mock-up. Model mock-up adalah suatu penyederhanaan susunan bagian pokok dari suatu proses atau sistem yang lebih ruwet.

Media trainer merupakan media yang tergolong kedalam kategori media model tiga dimensi. Media trainer ditujukan untuk menunjang pembelajaran peserta didik dalam menerapkan pengetahuan/ konsep yang diperolehnya pada benda nyata. Media trainer sistem kendali elektronik dikembangkan untuk mengatasi keterbatasan media yang ada. Pada trainer sistem kendali elektronik ini siswa dapat merangkai rangkaian berdasarkan joobsheet yang telah disediakan sehingga siswa lebih mudah memahami pelajaran menggunakan media trainer sistem kendali elektronik.

Setelah siswa melakukan pemasangan komponen sesuai dengan rangkaian yang ada maka siswa dapat mengukur rangkaian dan memahami cara menggunakan trainer sistem kendali elektronik. Dengan menggunakan media trainer sistem kendali elektronik ini diharapkan siswa dapat memahami dengan baik pelajaran mengoperasikan sistem kendali elektronik.

Media pembelajaran trainer sistem kendali elektronik dikatakan praktis jika dalam penggunaannya sedikit revisi atau tanpa revisi. Praktis secara praktek adalah hasil belajar siswa yang terdapat dalam lembar observasi siswa.

Media pembelajaran trainer sistem kendali elektronik dikatakan praktis apabila memenuhi syarat sebagai berikut:

a. Mudah dilaksanakan artinya dapat memberi kebebasan kepada siswa untuk mengerjakan hal yang mudah terlebih dahulu.

b. Mudah pemeriksaanya artinya bahwa siswa dapat memeriksa kekeliruan yang dilakukan sendiri.

c. Dilengkapi dengan petunjuk-petunjuk yang jelas sehingga siswa tidak kesulitan dalam menggunakan produk.

Efektivitas secara umum menunjukkan sampai seberapa jauh tercapainya suatu tujuan 
yang terlebih dahulu ditentukan. Departemen Pendidikan Nasional (2008), menyatakan bahwa efektivitas berarti ada efeknya (akibatnya, pengaruhnya, kesannya), manjur atau mujarab dan dapat membawa hasil. Efektivitas berkaitan dengan perbandingan antara tingkat pencapaian tujuan dengan rencana yang telah ditetapkan sebelumnya, atau perbandingan hasil nyata dengan hasil yang direncanakan.

Efektivitas penggunaan media trainer sistem kendali elektronik pada mata pelajaran mengoperasikan sistem kendali elektronik dapat diartikan bahwa keberhasilan yang dicapai setelah penggunaan media pembelajaran trainer sistem kendali elektronik. Keberhasilan kelas dapat dilihat dari jumlah peserta didik yang mampu mencapai minimal $85 \%$ dari jumlah peserta didik yang ada dikelas tersebut, dengan kriteria ketuntasan minimal yang diterapkan sekolah yaitu 75 .

\section{METODE}

Penelitian ini dikembangkan dengan model ADDIE (Robert Maribe Branch) yang terdiri dari lima tahap yakni Analysis, Design, Development, Implementation, dan Evaluation ( Sugiyono, 2015).

Tahap analisis (analysis) terdiri dari: analisis tujuan, analisis pengguna, dan analisis kebutuhan. Pada tahap desain (design) dilakukan perancangan dari trainer yang akan dikembangkan. Kegiatan pada tahap desain produk meliputi: (a) melakukan perencanaan awal, (b) membuat desain tertulis, (c) mempersiapkan komponen yang dibutuhkan, dan (d) melakukan pembuatan media trainer sistem kendali elektronik. Tahap pengembangan (development) media trainer sistem kendali elektronik dilakukan melalui beberapa tahap yaitu tahap validasi dan tahap uji coba. Pada tahap implementasi (implementation) media trainer sistem kendali elektronik yang telah dibuat diterapkan ke pengguna di lapangan. Evaluasi (evaluation) merupakan kegiatan menilai apakah setiap langkah kegiatan dan produk trainer yang telah dibuat sudah sesuai dengan spesifikasi atau belum.

Instrumen yang digunakan dalam penelitian ini menggunakan angket validitas dan angket kepraktisan. Tes objektif adalah tes yang dilakukan secara objektif. Pada mata pelajaran mengoperasikan sistem kendali elektronik tes objektif digunakan sebagai instrumen pengumpulan data hasil belajar siswa. Tes objektif diberikan kepada siswa setelah kegiatan pembelajaran menggunakan media trainer sistem kendali elektronik.

Uji validitas dilakukan untuk mengukur ketepatan alat ukur terhadap apa yang diukur. Suatu soal dikatakan valid apabila soal tersebut dapat mengukur apa yang hendak diukur. Untuk menghitung validitas tes menggunakan rumus yang dikemukakan (Suharsimi Arikunto, 2013: 93) sebagai berikut:

$$
\gamma_{p b i}=\frac{M_{p}-M_{t}}{S_{t}} \sqrt{\frac{p}{q}} \ldots . .
$$

Keterangan :

$\gamma_{p b i}=$ Koefisien korelasi point biserial

$M_{p}=$ Rerata skor dari subjek yang menjawab betul bagi item yang dicari validitasnya

$M_{t}=$ Rerata skor total

$S_{t}=$ Standar deviasi dari skor total

$p \quad=$ Proporsi siswa yang menjawab benar

$\mathrm{q}=$ Proporsi siswa yang menjawab salah

Setelah dilakukan analisis data menggunakan Microsoft Excel untuk soal uji coba instrumen penelitian posttest yang terdiri dari 30 soal, 5 soal diantaranya tidak valid, sedangkan 25 soal lainnya valid.

Untuk mengetahui reliabilitas digunakan rumus Kuder Richardson (KR-20) sebagai berikut:

$$
\mathrm{r}_{11}=\left(\frac{n}{n-1}\right)\left(\frac{s^{2}-\sum p q}{s^{2}}\right) \ldots
$$

\footnotetext{
Keterangan :

$r_{l}=$ Reliabilitas tes secara keseluruhan

$P=$ Proporsi subjek yang menjawab item benar

$Q \quad=$ Proporsi subjek yang menjawab item salah
} 


$$
\begin{array}{ll}
\Sigma p q & =\text { Jumlah hasil perkalian antara } p \text { dan } q \\
n & =\text { Banyaknya item } \\
S & =\text { Standar deviasi tes }
\end{array}
$$

Berdasarkan perhitungan reliabilitas menggunakan rumus KR-20, didapat nilai reliabilitas soal uji coba post test sebesar 0,839. Setelah disesuaikan dengan klasifikasi indeks reliabilitas, keseluruhan soal uji coba instrumen post test penelitian diklasifikasikan pada tingkat reliabilitas sangat tinggi.

Taraf kesukaran digunakan untuk mengetahui apakah soal tersebut tergolong mudah atau sukar. Taraf kesukaran dihitung dengan rumus:

$$
\mathrm{P}=\frac{B}{J S}
$$

Keterangan:

$$
\begin{aligned}
& \mathrm{P}=\text { Taraf Kesukaran } \\
& \mathrm{B}=\text { Banyaknya siswa yang menjawab } \\
& \text { benar } \\
& \text { JS = Jumlah seluruh siswa peserta tes }
\end{aligned}
$$

Setelah dilakukan analisis data untuk soal uji coba instrumen post test yang terdiri dari 30 soal, 6 soal memiliki tingkat kesukaran dengan kriteria mudah dan 24 soal dengan kriteria sedang.

Daya pembeda dihitung dengan rumus sebagai berikut:

$$
\mathrm{D}=\frac{B_{A}}{J_{A}}-\frac{B_{B}}{J_{B}}
$$

Keterangan :

$J \quad=$ Jumlah peserta tes

$J_{A}=$ Banyaknya peserta kelompok atas

$J_{B} \quad=$ Banyaknya peserta kelompok bawah

$B_{A}=$ Banyaknya peserta kelompok atas yang menjawab benar

$B_{B}=$ Banyaknya peserta kelompok bawah yang menjawab salah

Berdasarkan perhitungan daya beda dan disesuaikan dengan klasifikasi indeks daya beda soal post test, didapat 2 soal dengan kategori baik, 23 soal dengan kategori cukup, dan 5 soal dengan kategori sukar.

Teknik Analisis Data yang digunakan dalam penelitian ini yaitu Analisis Validitas Media Trainer, Analisis Kepraktisan Media Trainer dan Analisis Efektifitas Media Trainer

\section{HASIL DAN PEMBAHASAN}

Analasis tujuan pembelajaran menggunakan media trainer sistem kendali elektronik bagi siswa adalah sebagai salah satu alat bantu belajar dan untuk melatih keterampilan psikomotor siswa, bagi guru pembelajaran menggunakan media trainer sistem kendali elektronik dapat digunakan sebagai media pembelajaran dalam menyampaikan materi, dan bagi sekolah, trainer sistem kendali elektronik dapat menambah jumlah trainer yang dimiliki sekolah. Analisis pengguna trainer sistem kendali elektronik adalah siswa kelas XI TITL di SMKN 2 Lubuk Basung.

Pada mata pelajaran mengoperasikan sistem kendali elektronik terdapat materi membuat rangkaian kendali elektronik sederhana. Penggunaan media trainer yang belum optimal menjadikan kegiatan pembelajaran belum maksimal. Dari fakta tersebut dapat dilakukan pengembangan trainer sistem kendali elektronik untuk menambah trainer yang dimiliki sekolah sekaligus sebagai media pembelajaran siswa kelas XI TITL.

Untuk mengetahui pelaksanaan kegiatan belajar disekolah, salah satu sumber informasi adalah guru. Pada penelitian ini dilakukan wawancara dan pengisian lembar potensi masalah dengan guru mata pelajaran untuk mengetahui pelaksanaan kegiatan belajar. Wawancara dan lembar potensi masalah juga bertujuan untuk mengetahui kegiatan pembelajaran serta penggunaan media dalam belajar.

Berdasarkan hasil wawancara dan pengisian lembar potensi masalah diketahui bahwa pelaksanaan proses belajar belum maksimal. Media yang digunakan belum optimal membantu tercapainya tujuan pembelajaran. Ini terbukti bahwa ada beberapa materi yang seharusnya membutuhkan media dalam penyampaiannya, tetapi pelaksanaanya disampaikan secara verbal. Dari hasil wawancara membuktikan bahwa media pembelajaran berperan penting dalam 
penyampaian materi pelajaran mengoperasikan sistem kendali elektronik.

Agar media yang dikembangkan relevan dengan tujuan pembelajaran mata pelajaran mengoperasikan sistem kendali elektronik, maka dilakukan analisis kebutuhan penggunaan media pembelajaran menerut peneliti. Tujuannya untuk mengetahui media yang dapat digunakan sehingga siswa mudah memahami materi yang terdapat pada KD dan Indikator mata pelajaran mengoperasikan sistem kendali elektronik Kebutuhan media pembelajaran dapat dilihat pada tabel 1.

Tabel 1. Kebutuhan Media Pembelajaran

\begin{tabular}{|c|c|c|}
\hline $\begin{array}{c}\text { Kompetensi } \\
\text { Dasar }\end{array}$ & Indikator & $\begin{array}{l}\text { Media yang } \\
\text { Dibutuhkan }\end{array}$ \\
\hline $\begin{array}{l}\text { Membuat } \\
\text { rangkaian } \\
\text { kendali } \\
\text { elektronik } \\
\text { sederhana }\end{array}$ & $\begin{array}{llr}\text { - } & \text { SCR } & \text { digunakan } \\
& \text { sebagai } & \text { kontrol } \\
& \text { lampu } & \\
\text { - } & \text { Transistor } & \\
& \text { digunakan } & \text { sebagai } \\
& \text { kontrol lampu } \\
\text { - } & \text { TRIAC } & \text { digunakan } \\
& \text { sebagai } & \text { kontrol } \\
\text { lampu r } & \\
\text { IC } & \text { digunakan } \\
\text { sebagai } & \text { kontrol } \\
\text { lampu } & \end{array}$ & 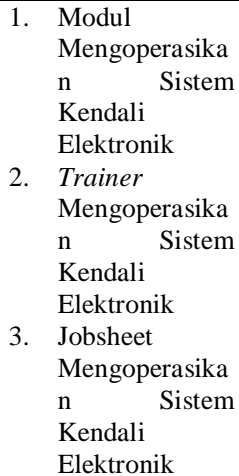 \\
\hline
\end{tabular}

Desain produk mengacu pada karakteristik siswa, hasil wawancara, lembar potensi masalah, dan analisis kebutuhan media. Landasan dalam melakukan desain produk mengacu pada pendapat Sugiyono (2008: 301) menyatakan bahwa desain produk harus diwujudkan dalam gambar atau bagan, sehingga dapat digunakan sebagai pegangan untuk menilai dan membuatnya. Kegiatan dalam mendesain produk terbagi menjadi empat yaitu : 1) Melakukan Perencanaan, Perencanaan dilakukan dengan mengacu pada hasil wawancara dan hasil pengisian lembar potensi masalah serta kebutuhan media pada mata pelajaran mengoperasikan sistem kendali elektronik. Berdasarkan hasil wawancara, hasil lembar potensi masalah dan kebutuhan media, maka dapat disimpulkan media yang selama ini digunakan belum optimal sehingga menghambat proses pembelajaran. Oleh karena itu media trainer sistem kendali elektronik dikembangkan dengan harapan dapat menjawab kelemahan dari media sebelumnya, 2) Membuat Desain, setelah membuat perencanaan media, selanjutnya membuat rancangan desain awal media trainer sistem kendali elektronik.

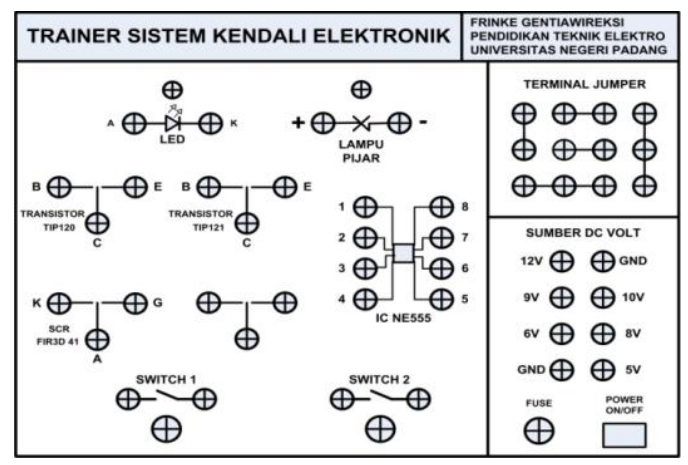

Gambar 2. Desain Awal Media

3) Mempersiapkan komponen yang dibutuhkan, 4) Melakukan pembuatan media trainer sistem kendali elektronik, setelah dilakukan perencanaan, desain awal, hingga persiapan komponen-komponen, selanjutnya masuk ke pembuatan media trainer sistem kendali elektronik. Pembuatan trainer dilakukan dalam berbagai tahapan mulai dari Pembuatan kotak papan trainer, Kedudukan Trafo, Kedudukan Komponen Trainer dan Proses Akhir (finishing)

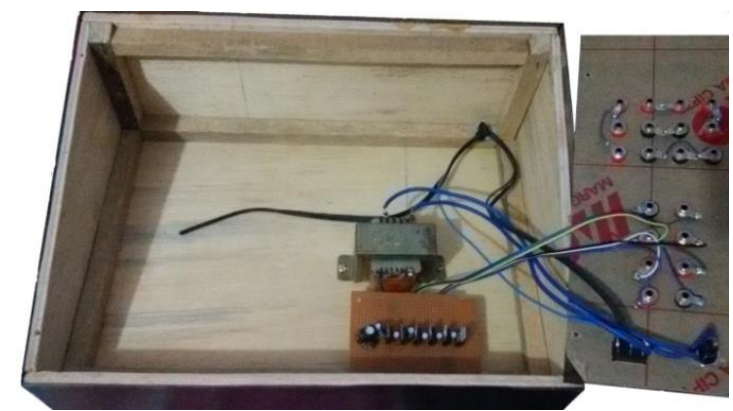

Gambar 3. Kotak papan trainer

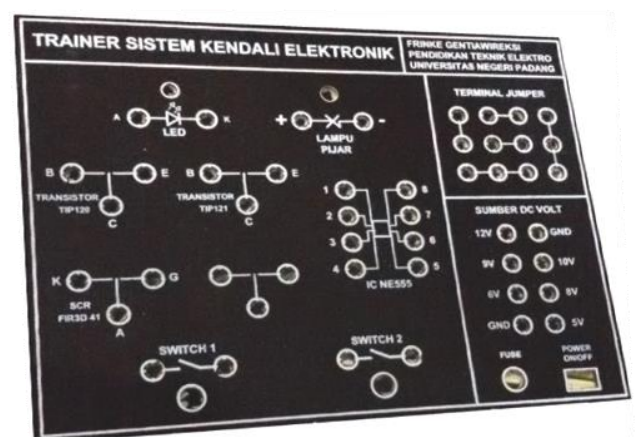

Gambar 4. Proses akhir (finishing) 


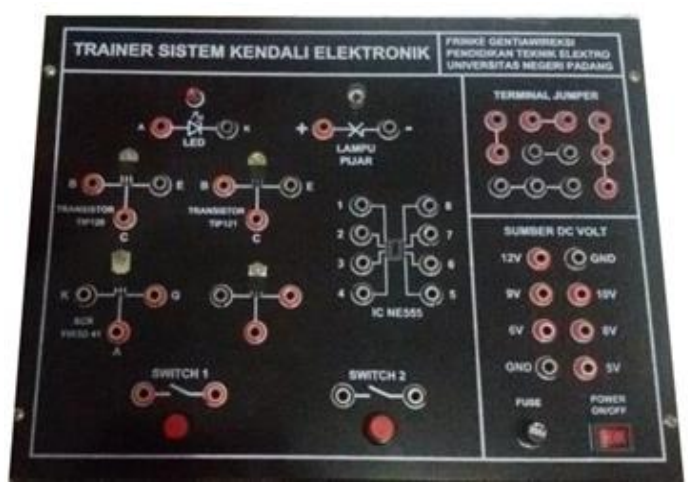

Gambar 5. Hasil pembuatan trainer

Setelah media trainer sistem kendali elektronik divalidasi oleh validator, dilakukan rekapitulasi data hasil seperti pada tabel 2 .

Tabel 2. Hasil Validitas oleh Validator

\begin{tabular}{l|l|l|l}
\hline No & Angket & K & Kategori \\
\hline 1 & 1 & 1 & Sangat Tinggi \\
\hline 2 & 2 & 0,94 & Sangat Tinggi \\
\hline 3 & 3 & 0,82 & Sangat Tinggi \\
\hline 4 & 4 & 0,82 & Sangat Tinggi \\
\hline 5 & 5 & 0,94 & Sangat Tinggi \\
\hline 6 & 6 & 1 & Sangat Tinggi \\
\hline 7 & 7 & 0,75 & Tinggi \\
\hline 8 & 8 & 1 & Sangat Tinggi \\
\hline 9 & 9 & 0,94 & Sangat Tinggi \\
\hline 10 & 10 & 0,75 & Tinggi \\
\hline 11 & 11 & 1 & Sangat Tinggi \\
\hline 12 & 12 & 1 & Sangat Tinggi \\
\hline 13 & 13 & 0,75 & Tinggi \\
\hline 14 & 14 & 1 & Sangat Tinggi \\
\hline 15 & 15 & 1 & Sangat Tinggi \\
\hline $\begin{array}{l}\text { Rata-Rata Hasil } \\
\text { Validasi }\end{array}$ & 0,91 & Sangat Tinggi \\
\hline
\end{tabular}

Rekapitulasi hasil presentase uji coba praktikalitas oleh siswa sebagai responden dijelaskan dalam tabel 3.

Tabel 3. Hasil Uji Coba Praktikalitas Siswa

\begin{tabular}{|c|c|c|c|c|}
\hline No & $\begin{array}{c}\text { Respon- } \\
\text { den }\end{array}$ & $\begin{array}{l}\text { Skor } \\
\text { Max }\end{array}$ & $\begin{array}{c}\text { Persen- } \\
\text { tase }\end{array}$ & Kategori \\
\hline 1 & 1 & \multirow{12}{*}{125} & $88 \%$ & Praktis \\
\hline 2 & 2 & & $86 \%$ & Praktis \\
\hline 3 & 3 & & $84 \%$ & Praktis \\
\hline 4 & 4 & & $93 \%$ & Sangat Praktis \\
\hline 5 & 5 & & $84 \%$ & Praktis \\
\hline 6 & 6 & & $88 \%$ & Praktis \\
\hline 7 & 7 & & $89 \%$ & Praktis \\
\hline 8 & 8 & & $91 \%$ & Sangat Praktis \\
\hline 9 & 9 & & $92 \%$ & Sangat Praktis \\
\hline 10 & 10 & & $84 \%$ & Praktis \\
\hline 11 & 11 & & $84 \%$ & Praktis \\
\hline 12 & 12 & & $85 \%$ & Praktis \\
\hline
\end{tabular}

\begin{tabular}{|c|c|c|c|c|}
\hline No & $\begin{array}{c}\begin{array}{c}\text { Respon- } \\
\text { den }\end{array} \\
\end{array}$ & $\begin{array}{l}\text { Skor } \\
\text { Max }\end{array}$ & $\begin{array}{c}\text { Persen- } \\
\text { tase }\end{array}$ & Kategori \\
\hline 13 & 13 & & $86 \%$ & Praktis \\
\hline 14 & 14 & & $94 \%$ & Sangat Praktis \\
\hline 15 & 15 & & $90 \%$ & Sangat Praktis \\
\hline 16 & 16 & & $87 \%$ & Praktis \\
\hline 17 & 17 & & $88 \%$ & Praktis \\
\hline 18 & 18 & & $92 \%$ & Sangat Praktis \\
\hline 19 & 19 & & $91 \%$ & Sangat Praktis \\
\hline 20 & 20 & & $88 \%$ & Praktis \\
\hline 21 & 21 & & $86 \%$ & Praktis \\
\hline 22 & 22 & & $87 \%$ & Praktis \\
\hline 23 & 23 & & $91 \%$ & Sangat Praktis \\
\hline 24 & 34 & & $88 \%$ & Praktis \\
\hline 25 & 25 & & $88 \%$ & Praktis \\
\hline 26 & 26 & & $92 \%$ & Sangat Praktis \\
\hline 27 & 27 & & $84 \%$ & Praktis \\
\hline 28 & 28 & & $91 \%$ & Sangat Praktis \\
\hline \multicolumn{2}{|c|}{$\begin{array}{c}\text { Persentase } \\
\text { Rata-rata }\end{array}$} & & $88 \%$ & Praktis \\
\hline
\end{tabular}

Hasil penelitian menunjukkan bahwa jumlah siswa yang memperoleh nilai $\geq 75$ adalah 25 orang siswa sedangkan yang $<75$ adalah 3 orang siswa. Mengacu pada kriteria efektif berdasarkan siswa tuntas yang telah ditetapkan dalam persentase keefektivan, maka media dikatakan efektif dengan persentase siswa tuntas memperoleh $89,3 \%$.

Pada tahap implementasi, produk atau media trainer sistem kendali yang telah dibuat diterapkan ke pengguna di lapangan. Pengguna dari produk ini adalah siswa kelas XI TITL SMKN 2 Lubuk Basung. Tahap ini dilakukan untuk memperoleh data berupa respon dan nilai keterampilan atau hasil belajar psikomotor siswa.

Tahap Evaluasi dilakukan dengan menganalisis data hasil penelitian yang diperoleh yaitu analisis kevalidan media trainer sistem kendali elektronik dari hasil angket oleh dosen teknik elektro FT UNP dan guru TITL SMKN 2 Lubuk Basung. Analisis kepraktisan media trainer dari hasil angket oleh guru mata pelajaran TITL dan 28 siswa kelas XI TITL. Analisis hasil post test siswa diperlukan untuk mengetahui keefektivan media trainer sistem kendali elektronik terhadap pembelajaran.

Data hasil validasi oleh validator digunakan untuk mengetahui kelayakan media trainer sistem kendali elektronik. Data angket respon guru dan siswa digunakan untuk 
mengetahui respon atau tanggapan siswa terhadap media trainer sistem kendali elektronik yang dikembangkan dalam pembelajaran di kelas. Data hasil post test digunakan untuk melihat keberhasilan dari media trainer sistem kendali elektronik yang dikembangkan di kelas.

\section{SIMPULAN}

Berdasarkan dari hasil analisis data dapat disimpulkan bahwa penelitian pengembangan perangkat pembelajaran ini telah menghasilkan produk berupa media trainer sistem kendali elektronik yang valid, praktis, dan efektif untuk Mata Pelajaran Mengoperasikan Sistem Kendali Elektronik (MSKE) kelas XI TITL SMKN 2 Lubuk Basung.

Hasil validasi media dan validasi materi memperoleh rata-rata moment kappa hasil validasi sebesar 0,91 berkategori sangat tinggi. Hasil uji praktikalitas media trainer mengoperasikan sistem kendali elektronik divalidasi oleh 2 responden yang terdiri dari 1 guru mata pelajaran mengoperasikan sistem kendali elektronik yang memperoleh persentase nilai $82 \%$ dengan kategori praktis dan 28 siswa kelas XI TITL sebagai pengguna media pembelajaran memperoleh persentase nilai sebesar $88 \%$ dengan kategori praktis.

Media trainer mengoperasikan sistem kendali elektronik efektif digunakan sebagai media pembelajaran dalam mata pelajaran mengoperasikan sistem kendali elektronik setelah dilakukan uji efektivitas. Pada uji coba efektivitas 89,3\% siswa dinyatakan memperoleh ketuntasan belajar. Sebagaimana persyaratan ketuntasan klasikal minimal $85 \%$ siswa harus tuntas.

\section{DAFTAR RUJUKAN}

Arief S Sadiman. 2009. Media Pendidikan. Jakarta: Rajawali Pers.

Asyhar Rayandra. 2012. Kreatif Mengembangkan Media Pembelajaran. Jakarta: Refrensi Jakarta.

Azhar Arsyad. 2013. Media Pembelajaran. Jakarta: Rajawali Pers.

Daryanto. 2010. Media Pembelajaran. Yogyakarta: Gava Media.

Depniknas. 2008. Kamus Besar Bahasa Indonesia. Jakarta: Balai Bahasa.

Hamalik. 2000. Psikologi Belajar dan Mengajar. Bandung: PT Sinar Baru.

Nana Sudjana. 2010. Strategi Pembelajaran. Bandung: Falah Production. . 2011. Media Pengajaran. Bandung: Sinar Baru Algesindo Offset.

Slameto. 2010. Belajar dan Faktor- Faktor yang Mempengaruhi. Jakarta: Rineka Putra.

Sugiyono. 2015. Metode Penelitian \& Pengembangan Research and Development. Bandung: Alfabeta.

Suharsimi Arikunto. 2013. Dasar-dasar Evaluasi Pendidikan. Jakarta: Bumi Aksara.

Sukmadinata. 2011. Landasan Psikologi Proses Pendidikan. Bandung: PT Remaja Rosdakarya.

Syaiful B Djamarah. 2010. Strategi Belajar mengajar. Jakarta: Rineka Cipta.

Syaiful Sagala. 2012. Konsep dan Makna Pembelajaran. Bandung: Alfabeta. 